\title{
3 Literature, Subject and Veridiction
}

\subsection{Raymond Roussel: The Political Subject of Literature}

The critical consciousness of literature has become infinitely close to the consciousness of the lyrical madman.

Folie, langage, littérature, 122

As we have seen, the relationship between literature and the extralinguistic passes through the "situation" and the "subject that speaks" inside the act of writing. The latter is the core of the relationship: "the position of the subject that speaks is the core of uncertainty around which the whole discourse vibrates" (Foucault, Folie, langage, litterature, 227). To the extent that the position of the subject that speaks is the extralinguistic that is most immediate, closest to the language, but the most irreducible, this presence of the subject that speaks inside the discourse is crucial it makes manifest the irreducibility of literature to the structures of language. The position of the subject that speaks, their location, the displacements they constitute, as opposed to what is said (lekton), the lexicon of the work. It should immediately be evident that this lexicon - as with fiction - is not so much an element of the work or discourse as ways via which literature and the extralinguistic are connected:

\footnotetext{
Just as between the universe of the discourse and the fable a certain level has been discovered that did not belong under linguistics or the study of folklore or myths, but under literature alone (this is what was called fiction), in the same way, between the field of the word and that of the lekton (the former being the concern of philosophy and the latter stylistics), there is a strictly literary level that comes under lexis.
}

Literature is a discourse whose fable is constituted by a fiction: it is a speech act the lekton of which is determined by a lexis. Lexis and fiction are privileged and singular domains of literary analysis. They fall under neither a philosophical model nor a linguistic one.

(Folie, langage, littérature, 259)

For this reason, we need to reflect on the relationship between literature and subjectivity. As we have seen in the second chapter, madness, as a mode of social partition, entails the seclusion of a type of negative, unproductive subjectivity, which is that of the insane. At the same time, Foucault asserted that in modernity madness has been associated with literature and, in the 20th century, with mental illness as well, as the two are confused. Therefore, the issue is whether the question why modern literature is not a viable route toward the question concerning the new humane practices - that is, concerning alternative ways of being to the concept of the modern man, or in Foucault's words, the literature of 
Roussel creates "forms without parentage or species" (Foucault, Death and the Labyrinth, 21). Death and the Labyrinth, the only writing devoted exclusively to the analysis of a literary work, is presented as a special place for this work: the madman, the ill person and the writer come together under the same proper name. His aim, Foucault constantly repeats, is to "show" the reader the thresholds of Roussel's work. This meticulous commentary on Roussel's work, which in turn starts with another commentary (How I Wrote Certain of My Books), repeating the mise-en-abyme structure that is very common in the writing of the poet and novelist, is at the basis of Foucault's thought on literature. In this early Foucault, the analysis of literature is also the politics of literary form.

As mentioned, in Foucault's early work there was already an interest in the politics of literature, in relation to the outside/extralinguistic of the text. As Foucault's studies on literature in the 1960s were a kind of laboratory where he was already posing some of these questions. I have shown how Foucault, in texts from the latter half of the sixties, sets forth the performative capacity of the literary text. This performative capacity, which depends on the immanent relation between literature and the extralinguistic outside, allows literature to state three types of truth: literature is able to speak of and intervene in the historical reality in which it takes place and it is also able to make visible what is invisible due to the social partition between right and wrong and between productivity and unproductivity. This capacity to say the truth is, in Foucault's terms, its capacity to say-everything, because literature, as fiction, is capable of naming the possibilities of every historical moment - heterotopia -, of "heroizing the present". This reflection on the politics of form is developed in a joint manner with his revision of structuralism, as he states in "Interview avec Michel Foucault" in 1968:

In a positive manner, we can say that structuralism investigates above all an unconscious. It is the unconscious structures of language, of the literary work, and of knowledge that one is trying at this moment to illuminate. In the second place, I think that one can say that what one is essentially looking for are the forms, the system, that is to say that one tries to bring out the logical correlations that can exist among a great number of elements belonging to a language, to an ideology (as in the analyses of Althusser), to a society (as in LéviStrauss), or to different fields of knowledge; which is what I myself have studied.

(Dits et écrits $I, 654)$

Foucault had found, in his interest for Structuralism and for the unusual linguistic forms of Raymond Roussel, modes of experimentation in his search for new structures of relation and novel forms of being as aesthetics of existence. As Judith Revel has stated, it is the production of the new through new relations between what is already there. Furthermore, for this rereading, it is necessary to look at two clearly recognizable traits for literary tradition. First, Foucault paints a kind of "portrait", genuinely Mannerist, in the style of the "Self-portrait in a convex mirror" by 
Parmigianino, a tradition in which Roussel could also be included - as John Ashbery has already considered:

At the moment of his death, in a gesture both cautious and illuminating, Roussel holds up to his work a mirror possessed of a bizarre magic: it pushes the central figure into the background where the lines are blurred, placing the point of revelation at the farthest distance, while bringing forward, as if for extreme myopia, whatever is farthest from the moment of its utterance. Yet as the subject approaches, the mirror deepens in secrecy.

(Death and the Labyrinth, 4)

And, on top of this, another story, that of the death of Roussel, and that locked door that sets in motion the How I Wrote Certain of My Books, and which refers to the hermeneutic tradition, distancing himself from it, because it transforms into an enigma the process that he clarifies: "This door, which had been open at all times, was locked from the inside. The death, the lock, and this closed door formed, at that moment and for all time, an enigmatic triangle where Roussel's work is both offered to and withdrawn from us [...] a simple key which is marvellously ambiguous, ready in one turn either to lock in or to open up" (6). Origen, in Philokalia, tells this parable on the interpretation of the sacred Scriptures, referring to the origin of hermeneutics:

Inspired Scripture taken as a whole was on account of its obscurity like many locked-up rooms in one house: Before each room he supposed a key to be placed, but not the one belonging to it; and that the keys were so dispersed all round the rooms, not fitting the locks of the several rooms before which they were placed.

(Origen, The Philocalia, 32)

This presentation introduces the work in the Mannerist tradition and distances it from the tradition of classical hermeneutics. Death and the Labyrinth is not a work on how to interpret its true meaning. On the contrary, the comment that ought to clarify, "opens a space of infinite uncertainty" (Foucault, Death and the Labyrinth, 11). Therefore, what is the truth of which Roussel speaks as a discovery of the formal procedures with which he writes his book? This truth is not an unveiling, his "truth" is other, that of the mechanisms of self-representation of language, typical of the Mannerist tradition. Recall Deleuze's definition of Mannerism in his lecture series on the Baroque, delivered at Vincennes in 1987, as the evental logic of substance - the predicate is always event, says Deleuze. In other words, Mannerism refers to the definition of the subject by his/her ways, by which logic the being ceases to be attributive, and comes to be predicative:

It will have to be said that Leibniz breaks with the scheme of attribution, and at the same time breaks with the essentialism of substance, of the substance constituted by an essence. To attribution it replaces predication, the predicate always being relation or event, 
and to essentialism it will substitute what? So here we can be all happy to have found a word, I say it very quickly, let's call it mannerism.

(Deleuze, Sur Leibniz)

The evental logic of literature and its relation with the unknown processes of subjectification was fully developed by Foucault in his lectures on Sade, but in my opinion it is in Death and the Labyrinth that Foucault lays out an early version of evental subjectivity. The forms of being, their ways, such as event, are described through two principal processes: paradoxical statements, which the very subheadings of Foucault's book indicate ("the threshold and the key", "rhyme and reason", "the metamorphosis and the labyrinth", "the empty lens", "the enclosed sun") and the constant use of polysemic terms or phrases, which show the introduction of difference in identity and, at the same time, the same impossibility of the closure of meaning. These formal processes show us the impossibility of attributively confirming subjectivity. Good meaning, such as closed and certain meaning, is impossible. Paradox and polysemy are the affirmation of two meanings at the same time, and they affect both language and the impossibility of defining a subjectivity as fixed identity. At the same time, the extralinguistic - as the capacity of literary language to name the invisible material - also forms part of the study, as it does in all literature. In this regard, Foucault on Roussel's La Vue: “everything can be seen from afar, but with a stare that is so penetrating, so supreme and so neutral that even the invisible rises to the surface under a unique, immobile and even light" (Foucault, Folie, langage, literature, 279). Moreover, the descriptions of Roussel's works reveal the formal and untamed gaps of resistance to the discursive mechanisms of power. Roussel's literature, above all thanks to the reduplication of his How I wrote certain of my books, is an act of making see the possible non-existent. Modern literature, as opposed to what Aristotle expounded in his Poetics, utilizes its own negativity to "make see": "The Nouvelles Impressions can only be described by what they are not" (Folie, langage, literature, 123).

Finally, Death and the Labyrinth is an exercise in criticism, literary criticism but above all criticism of the social partition, aiming there where the identity of reason is placed face to face with the identity of Unreason. The procedures of Roussel's writing show that language and identity cross where the partition of the social mixes, indifferently, madness and literature. And this is so because Roussel's work is "one of those rare cases in which the work, the experience of madness and mental illnesses are precisely superimposed to form a single figure" (Folie, langage, literature, 116).

While, as Foucault declares, "we could say that there is not one single society in which it is permitted to say everything", literature - as writing of madness - is the discourse of excess that speaks beyond what a society allows in a given historical moment. A political study of form allows Foucault to show how literature thus 
coincides with madness, insofar as it is a category of social organization, through fiction. In modernity, literature succeeds in making see: a part of reality that stays hidden (the necessary as the excluded), the processes by which literature creates (being of language: mechanism of self-representation of language) and the possible forms of subjectification that the fiction of every episteme allows (and the contingent as the historical possible non-existent). Thus, literature has a paradoxical nature for Foucault: the extralinguistic, as the limit of the autonomy of literature, is inserted like a fold in literature. This is why literature can also affect the historical extralinguistic.

I consider that this performative intervention of literature on the extralinguistic, as criticism of the partitions between reasonable-productive subjects and unreasonable-unproductive subjects, is an early development of some aspects of the critical discourse of parrhesia that Foucault elaborated in the 1980s. It establishes an underground link between madness, literature and parrhesia, in short, between literature and the political history of truth, which is of great interest both for the political studies of current literature and for the necessary revision of the Foucauldian oeuvre in the light of the unseen writings that are to be published in the coming years.

\subsection{Sade: Irregular Subjects and the Politics of Desire}

Daniele Lorenzini states in "Le désir comme 'transcendantal historique' de l'histoire de la sexualité" that although desire did not receive systematic attention in Foucault's work, it undoubtedly played a crucial strategic role in his oeuvre. But it is from 1981, as per Lorenzini, when the fundamental problem of the history of sexuality becomes: "quelle expérience pouvons-nous faire de nous-mêmes, quel type de subjectivité est lié au fait que nous sommes toujours en possibilité et en droit de dire: 'Oui, c’est vrai, je désire?’” (139).

For Foucault, the history of desire is interwoven with the history of the Western subject, since, as he states in the Subjectivité et vérité lecture series, the discourse on the truth of sexuality, in our Western societies, is organized around the practice of confession, that is to say, as obligatory discourse of the subject on themselves and their desire. This takes place from the profound transformation that the Greek practice of aphrodisia suffered in the Roman era, when sexual ethics became more and more centred on the conjugal relation. According to Foucault, in the imperial Roman period, the principle of sociosexual isomorphism is radically called into question by an overvaluation of marriage. It is then, Foucault states, that a permanent relation is established between the subject and their own sex, under the form of their desire; and it is 
because of this that the control, domination and knowledge of their desire will determine the subject that is in genesis of the modern subject. Thus the "subject of desire" is born, in which desire is in no way identified with pleasure, in the same way that interiority is not identified with intensity either (Lorenzini, "The Emergence of Desire", 460).

This subject of desire will be determined, between the first century BCE and the first century CE, in its access to the truth about itself, through sexual activity. This will be the reason for which this truth cannot be attained, and why its purification will be needed:

Bref, c'est le christianisme (et notamment le monachisme) qui a noué "ce rapport de la subjectivité et de la vérité à propos du désir, qui est si caractéristique non seulement du christianisme mais de toute notre civilisation et de tout notre mode de pensée".

(Lorenzini, "Le désir comme 'transcendantal historique”, 145)

Therefore, desire and duty coincide in the configuration of a concept of subject that is both political and ethical. But more decisive is the consideration of the common good in this truth-telling of a free subject, because this practice is a critique and, in this sense, the subject that practises it puts his/her own life at risk. The definition of a free subject cannot, nonetheless, be configured other than in interrelation with others, and whose desire to live is, at the same time, a risk and a desire - returning to the concept of life as struggle between Freud's drive for death and life. It is central to understanding the scope of Foucault's political aesthetics. I will return to this topic in the next chapter. Before then I will analyze the lectures that Foucault gave on Sade in 1970, at the University of Buffalo. In these lectures, Foucault focuses his attention on Sade's statement, "I only tell the truth" as an emancipatory logic of discourse.

There was certainly a great deal published on Sade in the 1970s. But if there is a key debate for understanding the scope that this text had in the last phase of Foucault's oeuvre, it is the one Foucault's text held with Dialectic of Enlightenment, by Max Horkheimer and Theodor Adorno, published in 1944. We can find the clues to understanding particularly in the chapter that Adorno and Horkheimer devote to "Juliette, or Enlightenment and Morality" (Dialectic of Enlightenment, 63-93), in which they analyze how Sade's literature aims to unblock the incapacity of Kantian thinking to undermine the order that had been made repressive, insofar as it is linked, ultimately, to the mode of dominant production (73). According to their perspective, the work of Sade, along with that of Nietzsche, was an intransigent critique of practical reason, which exposes a disturbing truth: "the indissoluble alliance of reason and atrocity" (92). Adorno and Horkheimer conclude that Sade's work elevated the scientific principle to the destructive principle, or what they called the amor intellectualis diaboli, the 
joy of defeating civilization with its own weapons. For the authors, and particularly for the Adorno of Negative Dialectics (1970), the anti-Hegelian logic of Sade's writings produces a truth: "the identity of power and reason" (93).

Foucault, for his part, who also begins with the critique and revision of Kant's proposal of Enlightenment, adds to the consequences of this anti-philosophy of the Enlightenment, to the power of the negativity of Sade's logic described by the Frankfurt theorists, the analysis of the performative powers of identity that are also found in this logic. Foucault analyzes how the modes of veridiction of Sade's characters not only embody the powers of science but also, in their "truth-telling", put forward modes of emancipation from the subjectivities in what we can call a performative negativity or material negativity. ${ }^{6}$ In other words, it would now not only be a thought of enlightened negativity but also of the performativity of the truth-telling of irregular subjects, crucial in Foucauldian thought of the 1970s and 1980s (infamous subjects). This concept of performative negativity, that which evolves out of the non-attributive logic of Sade, supposes an overcoming of the opposition between truth and desire, as will be seen.

In the second of the two lectures that he gave in Buffalo, Foucault tackles the subject matter of the character of the libertine as irregular form of being, as "irregular existence". Unlike in the first lecture, in which the texts that form its basis are predominantly literary, in the second he undertakes a fundamental shift towards Sade's theoretical discourse with Idées sur le roman, in his global proposal to analyze the ten volumes of Justine and Juliette. Here Foucault states that Sade's procedure for writing does not entail a transgression of rational thought (law of alternation of discourses). On the contrary, for Foucault Sade's discourse proposes an alternative to rational thought but from within the same rational logic, in accordance with the reading already made by Adorno and Horkheimer. However, the works of Sade were not, for Foucault, the negative development of the other of reason. For him, we find a kind of resistance in these irregular characters - characters that represent a logic of thought that is also a model of resistance, just as he describes it in the second lecture.

Adorno and Horkheimer's interpretation, Dialectic of Enlightenment, had already stressed that the objective of the "Enlightenment" in a broad sense, common to Sade and Nietzsche, was to take away the fear of men, a liberation that, however, "copes with fear by defecting to the agencies that inspire it [...]. What is infernal about wrong laughter is that it compellingly parodies what is best, reconciliation" (112). In contrast, for Foucault, Sade's work, as deconstructor of

6 For a development of this question, see Section 2 of Chapter 5, "Donner à voir: politics of form and the Marxist tradition of literature". 
instrumental reason through the reversal of its effects in his novels, showed, in this ironic reversal, the possibility of emancipation of the subject faced with the imposed modes of "normalization". Foucault therefore argues against Adorno and Horkheimer and attributes to Sade's discourse a radically historical emancipatory force that was not contemplated in the rational reversal of Dialectic of Enlightenment. Foucault maintains that the non-existence of God is not a theoretical thesis, confirmed once and for all as a truth that could be deduced from reasoning. The inexistence of God is anything that is carried out at each moment as evil of God, as "evil of God in action", within the person and the conduct of the libertine. It could be said that Sade's logic carries out a similar function in Foucault's work as the logic of Leibniz in Gilles Deleuze's The Fold. Both non-attributive logics formulate a subjectivity at every moment, as historical radical of Da-sein.

In its working, Sade's logic is anti-Russellian: if the logic of Russell bases the existence of the subject independently to its relation with the predicate, the logic of Sade is the inverse: the judgement of the inexistence of the attribution is supported upon the subject of the attribution. It is a logic that is equally foreign to Cartesian logic. In effect, Descartes's logic is made using an attributive judgement and reaches an existential judgement. Conversely, Sade begins with an attributive judgement of attribution not to reach an existential judgement but rather one of nonexistence. With Foucault, one can say that Sade's logic is rigorously monstrous, since between the "intuitionist" logic of Descartes, that necessarily rests on the idea of the existence of the idea and, therefore, on a possibility, and the formalist logic of Russell, Sade has come to construct a form of logic that is absolutely nonviable in terms of logic and from a judgement of attribution, "he reaches a judgement of the nonexistence of the very thing about which the attribution is made" (Language, Madness, and Desire, 134). Therefore, this logic is a logic of the emancipation of the subject that is supported upon the subject of desire. Knowing and desiring coincide in Sade's proposal, overcoming the classical dialectic between the two.

As Judith Butler explains in Subjects of Desire (1987),

when philosophers have not dismissed or subdued human desire in their effort to become philosophical, they have tended to discover philosophical truth as the very essence of desire. [...] To desire the world and to know its meaning and structure have seemed conflicting enterprises, for desire has signified an engagement of limited vision, an appropriation for use, while philosophy in its theoretical purity has presented itself as not needing the world it seeks to know.

In the lecture that Foucault gives on Sade, the relation between desire and truth is neither a rational desire nor does it establish a causal relation between 
the two. It enables the subject to act in relation to the truth of the desire itself, a real "art of living", as he shows in The History of Sexuality. For example, in the statement "God does not exist", truth and desire are united in a complex relation: it is because God is evil that libertines exist and the crueller the desires of the libertines, the truer it is that God does not exist. The truth of the nonexistence of God and the multiplication of signs are thus connected to each other in a kind of unending process. The libertine annuls the laws of logic and of modern thought through desire. This is the desire of Sade's texts, desire as liberation-domination, desire as force that opposes, denies and destroys, in a system of power relations equally introduced in itself, folded upon itself: "God's nonexistence is fulfilled at every moment in Sadean discourse and desire” (Language, Madness, and Desire, 136).

Power and desire are the two faces of this tension of forces. As Walter Privitera states in Problems of Style: Michel Foucault's Epistemology (1995), "Foucault distinguishes between the 'will to knowledge', which characterizes the dominant form of power since Plato, and 'power' or 'desire' which can be dated back to time in ancient Greek history when the truth of a discourse coincided with the power of whoever uttered it" (Privitera, Problems of style, 67).

Nevertheless, these non-existent monstrosities that are God, others, crimes, laws, nature, etcetera, are not illusions in the understanding of the eighteenth century. That is to say, they are not illusions that once discovered we will feel free of. In response, Sade makes them "chimeras". The chimera is defined by Foucault not as something that does not exist but as something that possesses another type of existence. That is to say, it is the mode in which "performative negativity" acts as a way of overcoming the "desire/truth" dialectic. The chimera moves thus to Sade's logic that removes that barrier of time and establishes a repetitive world. Sade's logic guarantees that desire will always be true and nothing can ever invalidate it. It can be said that Sade's discourse does not suppose, as might be believed, the object of desire, but that desire and discourse are effectively the same object. Sade's writing introduces desire in the order of veridiction. The chimera sheds light on the same order of action in that which Foucault's definition of fiction made it. They show that the time of the fiction is historical but not teleological or progressive. And it is in this order that veridiction acts equally.

Foucault observes that these discourses vary according to different factors and depending on the situations. That is, there is no general system, there is no philosophy of Sade. Instead, there is a plurality of systems that are juxtaposed and that do not communicate with the others except through the network of the four fundamental theses (God, the soul, nature, law). Consequently, this discourse will have another function that consists of distinguishing in the very interior of the libertines that "the individuals cannot be reduced to one another", as 
the systems vary from individual to individual. There is thus no general system, as I have said, but one for each libertine, and this defines their singularity, what Sade calls "the irregularity of individuals". Every individual is irregular and their own irregularity is manifested, is symbolized, in their system, in what we can call their style or their manner, as defined by Marielle Macé (Styles: critique de nos formes de vie, 2016) and Giorgio Agamben (The Fire and the Tale, 2017), respectively.

Because of this, the true interlocutors to whom Sade's discourse is directed cannot be the victims. The true interlocutor, Foucault says, is the libertine other, is the one who is already emancipated by the work carried out on himself/herself. The discourse is directed from libertine to libertine, it does not aim to seduce. Therefore, the truth of Sade's text fulfils another of the key traits of parrhesia: it confronts persuasive rhetoric. In its repetitive telling it is capable of negating the existence - through the force of its writing - of God, the soul, nature or law. His writing is a "desire-passion" for writing, a writing that is capable of affirming other modes of being such that the libertine-subject is constituted as self-affirmation (when the libertine affirms herself, God is negated).

In this way, Sade frees the desire within the great Platonic edifice, where desire is adapted to the sovereignty of truth. In fact, more than freeing, for Sade, Foucault says, "desire and truth were neither subordinate to each other nor separable from each other. [...] 'Desire is unlimited only in truth, and truth is active only in desire,," and this does not at all mean that, in the form of now recovered happiness or peace, "desire and truth will merge into an authoritative figure in the form of happiness or a newly rediscovered peace. Rather, desire and truth are endlessly multiplied in the unfolding, the scintillation, the infinite continuation of desire" (Language, Madness, and Desire, 146). Ultimately, we can answer that the truth imperative that Sade attributes to his work, "I only tell the truth," coincides with the other "I desire". The truth of writing is desire as performative force that transgresses the order of discourses, on the one hand, and the opening of subjectivity to new forms of being as irregular forms that had not formed part of political positivity or presence.

Foucault's analysis of Sade in these lectures thus completes the brief attention he gives to him in The Will to Know. In the first volume of The History of Sexuality, Foucault presents Sade as a transgression while also a continuation of the Christian confessional practice of "telling all”. Although, in these Buffalo lectures, his work entails, on the one hand, an advance of what in the last years of his research, particularly after 1981 as Daniele Lorenzini (2016) has shown, was the crucial problem of the Foucauldian history of sexuality, to tackle those experiences that might make us and that enable us to say, "yes, it's true, I desire". And, on the other hand, the literary experience of Sade is analyzed here as an example of the negative modern experience of aphrodisia, 
as a set of actions that mark relations with oneself and with others. It may be said that, in the same way that criticism lingers "darkly" in Sade's madness, classical aphrodisia - that is, desire as principle of action - is taken up anew in the marquis's writing. In this way Sade gives fiction, in terms of desire, a critical and emancipatory capacity of the subject as creative subject of self.

One should make note here of a correlation not mentioned by Foucault, but which is fundamental: the similarity between Sade's logic of desire, Foucault's ethic of care for oneself, and Spinoza's ethic of desire, because in all of them, freedom is connected with desire. That is to say, there is not a determination through action but a transformation of subjectivity through desire itself. For Spinoza, desire is the essence of man - a desire that compels Spinoza's conatus to be dynamic, as the maintenance of being requires a force/strength, "a striving for perseverance”. Furthermore, in his definition of freedom at the beginning of the Ethics, Spinoza had already related truth with emancipation when he considered that the true idea is so because of its independence (Spinoza: Practical Philosophy, 1981). In Spinoza, freedom is not tied to will but to desire. The ethics of will to be is likewise problematized by Spinoza. As opposed to the dominion of the passions by the conscience, Spinoza's philosophy ceases to be a must-be and the soul is necessarily conscious of itself by means of the ideas of the affections of the body and is, therefore, conscious of its effort (conatus).

However, Foucault's study of Sade's work, as well as his examinations of other irregular or other infamous subjectivities, enables him to analyze the experience of the negativity of "mal faire", in contrast to the aesthetic of the "cura sui" typical of the classical era and Christian pastoral. This experience of infamous subjects, therefore, shows the other expelled from enlightened discourse. Desire and truth are not opposed in Sade's logic, in the same way that they are not in the classical concept of parrhesia as expounded by Foucault. Nevertheless, the status of literature, particularly of what Foucault calls "bad literature", that which compressed the definition of the literary institution, is capable of saying what does not want to be seen or heard and puts its epistemological status at risk. In short, literature, in its historical dimension, is capable of creating spaces of resistance through the introduction of excessive discursive practices that interrupt the normativity of a particular historical moment (or episteme). And they do so from the very interior of this system.

Literature, therefore, places at its centre the current debate for the search for alternative forms of narration in the crisis of the end of History. These narrative forms would belong to History itself and not to an outside: they are, using Giorgio Agamben's expression, "close at hand” (The Fire and the Tale, 22).

Ultimately, as a result, we can draw consequences in two directions. Firstly, revising the place that literature occupies in Foucault's work gives it a political force that enables the development of a fictional capacity as alternative narrative 
and a critical capacity as "making see/revealing", in his particular revision of the concept of the gaze in Western thought. Secondly, Sade's logic gives Foucault an alternative to the attributive logic that restrict the forms of being and that would be fundamental in the last stage of his philosophical production. And he advances, therefore, the link between truth and desire as performative truth in the subject, that subsequently develops in the concept of parrhesia in the lectures of the 1980s.

It is from this perspective that the consequences that the concept of fiction has in Foucault's work can be understood. Fiction, like desire, would function as a force that is no longer the power of the negative but the revealing of being at every instant as subject of self. Foucault's aesthetics are thus an ethics and a tekné of self. Hence, politics and ethics are at the basis of this concept. But more decisive is the consideration of the common good in this truth-telling of a free subject (parrhesia), because this practice is a critique and, in this sense, the subject that practises it puts his/her own life at risk. The definition of a free subject who cannot, as I have said, be configured other than in interrelation with others, and whose desire to live is a risk and a desire at the same time, is one of the core elements to understanding the scope of the political aesthetics of Foucault.

\subsection{Aesthetics of Existence: Technologies of Emancipation in Later Foucault}

As I have stated, Foucault's subject of desire traces its genealogy through the era of ancient Rome and up until our time. If Sade shows us the inverse way of the rational logic of "speaking truth" that ties our desire, in this section I wish to examine more deeply the "technologies of the self" as emancipation/subjection of the subject. The analysis of these technologies is directly related to the aesthetic of existence that Foucault worked on in the last years of his life.

To this end, I will focus on analysing Foucault's 1982 Vermont lectures. The intermediate position of these lectures in Foucault's philosophical trajectory enables us to see how he links the question of the care of self, belonging to hermeneutics, to the concept of speaking-truth from his later texts.

From the analysis of this genealogy of the care of self that Foucault traces, I will put forward some questions on the definition of a subject that, in their subjective care, is at the same time undertaking a care for the community. Foucault thus responded to his own critique on the concept of man that he made in the 1960s, proposing a concept of subject in constant process, a subject as action. Lastly, I will conclude with how these technologies allow the subject not to free but to resist the processes of domination. 
The later Foucault's proposal enables us to confront the challenge of an ethical subject who finds their model in Graeco-Roman technologies, wherein they care for the self in their retreat, whether through self writing, through meditation as recollection of self or of the subsequent technologies that Foucault describes in these lectures. This would enable us to consider retreat and its treatment in art and literature, not only from a modernist perspective (the ivory tower of the poet) or that of a community of recluses as a desire to flee (as Pascal Quignard shows in Sur l'idée d'une communauté de solitaires). In Foucault, solitude and the contemplation of death are the way to understanding a subject whose negativity is radically productive, because desire is traversed with this negativity.

Foucault bases the ethical and political origin of communities in the care and process of subjectivation. We should remember that it is the care of self that is at the basis of Greek democracy, in the figure of the parrhesiast. Two years later, Foucault would find the legacy of this subject in the ironic hero of Baudelaire:

Cette héroïsation ironique du présent, ce jeu de la liberté avec le réel pour sa transfiguration, cette élaboration ascétique de soi, Baudelaire ne conçoit pas qu'ils puissent avoir leur lieu dans la société elle-même ou dans le corps politique. Ils ne peuvent se produire que dans un lieu autre que Baudelaire appelle l'art.

(Dits et écrits I, 1390)

There the technologies of the self are in conjunction with lifestyle and the art of living - art in the sense of technique - of which Foucault would go on to speak in other lectures, those he gave at Berkeley in 1984. In this chapter, we will not get as far as the twentieth century, so as to concentrate on the origins of the technologies of the self, but this will help us to understand the framework of thought of the later Foucault in which these proposals are developed.

Regarding this genealogy of the technologies of the subject, Foucault is reconsidering his question concerning the possible emancipation of the subject. In his historical ontology of ourselves, Foucault says: "the aim is: the creation of freedom". And he adds:

Maybe the target nowadays is not to discover what we are but to refuse what we are. We have to imagine and to build up what we could be to get rid of this kind of political "double bind", which is the simultaneous individualization and totalization of modern power structures. The conclusion would be that the political, ethical, social, philosophical problem of our days is not to try to liberate the individual from the state and from the state's institutions but to liberate us both from the state and from the type of individualization which is linked to the state. We have to promote new forms of subjectivity through the refusal of this kind of individuality which has been imposed on us for several centuries.

(Technologies of the Self, 785) 


\subsubsection{Technologies of the Self. Introduction}

The Vermont lectures took place in 1982. In other words, between the Collège de France lectures on The Hermeneutics of the Subject (that concluded in March 1982) and his lecture series on The Government of Self and Others (which began in January 1983). Therefore, Foucault is focused on the study of the classical texts (from the period of Classical Greece until early Christianity) that go from the care of the subject by the subject up to reflecting upon the relations between subjectivity and government of the community, which led into his work on parrhesia in 1984 (his lecture series The Courage of Truth and the Berkeley lectures collected in Discourse and Truth). Thus ended the path that Foucault had set forth upon with the publication of the first volume of the History of Sexuality - in 1976 -, the fourth volume of which, The History of Sexuality: 4: Confessions of the Flesh, was only published in French in 2018.

Foucault differentiates between the hermeneutics of the self and the theologies of the soul. And he points out the difficulty of this study because these technologies are integrated into our culture in various types of activities and experiences ("Technologies of the Self", 47). The analysis of these technologies and their relation with the truth, as "games of truth", are the methodologies that men utilize in order to understand themselves ("Technologies of the Self", 48). Foucault thus defines the technologies of the self: they consist of a "number of operations on their own bodies and souls, thoughts, conduct, and way of being, so as to transform themselves in order to attain a certain state of happiness, purity, wisdom, perfection, or immortality" (48). Shortly I will look at the different methodologies entailed by the proposal of a genealogy that helps to answer the Foucauldian question, "how have we become what we are?" The question that Foucault keeps on the horizon is a question for the present ("What is Enlightenment?").

According to Foucault, the development of the technologies of the self had two phases: 1) Graeco-Roman philosophy in the first two centuries C.E. of the early Roman Empire; and 2) Christian spirituality and the monastic principles developed in the fourth and fifth centuries of the late Roman Empire. He discerns a notable difference between the technologies employed in the two periods. The main difference is based on the consequences that these technologies have in the shaping of the subject. In the Greek and Roman classics, subjectivity is a process, a continual dynamics of the soul; whereas the technologies of early Christianity consititute extreme attention to contemplation and obedience to the master. The subject is then constituted as passivity and vigilance over what might waken desire. Therefore, desire, as force of action in the former technologies - that "concern for self" - is set aside and placed under vigilance as the secret that must be shown and punished. 
Foucault describes in his lectures four types of technologies that participate in what he calls governability: technologies of production, technologies of sign systems, technologies of power and technologies of the self. For Foucault, the technologies of subjectivation and those of governability of others are closely related. He explains in this way the relations between the process of subjectivation and subjection - a concept of the contradictory subject that Judith Butler has developed extensively in her work -, and between power and resistance in the configuration of subjectivity.

\subsubsection{Technologies of the Self in Graeco-Roman Culture}

“The precept 'to be concerned with oneself' was, for the Greeks, one of the main principles of cities, one of the main rules for social and personal conduct and for the art of life" (50) and more so than the Delphic principle "know yourself". As Foucault said of Socrates: "in teaching people to occupy themselves with themselves, he teaches them to occupy themselves with the city" (52). Which is why Foucault revises the origin of ethics as technology and not as epistemology - which completely modifies the modern perspective of the predicative subject as opposed to the dynamic concept that Foucault presents here. The subject is continual movement, a dynamic concept. I quote: "As there are different forms of care, there are different forms of self" (53).

In Alcibiades we find the first appearance of the phrase, epimelesthai sautou. Epimelesthai is more than paying attention: it is a real activity, not just an attitude. In the Alcibiades, two questions are raised: "What is this self of which one has to take care, and of what does that care consist?" (58). The pseudoPlatonic dialogue once more places a dynamic and political approach in the centre: "What is the plateau on which I shall find my identity?" Alcibiades tries to find this self in a dialectical movement and decides that care of the self is the care for the soul. But what matters is not the soul as substance but the care of the activity. The soul is also defined as an activity, therefore. And for this work, the soul can only know itself by contemplating itself in a similar element, a mirror. Thus it must contemplate the divine element:

In $127 \mathrm{~d}$ of the Alcibiades we find the first appearance of the phrase, epimelesthai sautou. Concern for the self always refers to an active political and erotic state.

In this divine contemplation, the soul will be able to discover rules serve as a basis for behavior and political action. The effort of the soul to know itself is the principle on 
which just political action can be founded, and Alcibiades will be a good politician insofar as he contemplates his soul in the divine element.

Therefore, in the origin of the technologies of the self, occupation with oneself (the examination of one's soul) and political activities are mutually involved:

The care of self poses four main problems that have endured throughout history: its relationship with political activity, its relationship with teaching (an obligation that lasts throughout life), its relationship with knowing yourself (which characterizes all Platonists), and its relationship with philosophical love or the relation to a master.

$(60-1)$

The Stoics declared: "retire into the self and stay there," and it is still a central theme in philosophy. It was an active leisure: meditation and preparation. In this exercise, writing played an important role. Seneca's letters are an example of this exercise of self. The self is something that must be written about, it becomes the object of literary activity. The new concern with self entailed a new experience of self, in the first and second centuries, when introspection became more and more detailed (62). Thus a relationship between self, writing and vigilance was developed. Writing and care of the self opened up a new field of experience that had been absent until then: the subject is then configurated as liberation and repression, at the same time.

Moreover, this first self-writing was also occupied with the body. By way of example, Foucault quotes the letter that Marcus Aurelius wrote to his tutor Fronto, in which Marcus Aurelius describes his day in detail, with references to his health and body, and the theme of which is ars erotica. ${ }^{7}$ Furthermore, this letter alludes to the examination of conscience at day's end, which is prefigured in this letter writing, as well as in the Christian confession, and later in diary writing - although, Foucault explains, the diary more strictly originates in the Christian era and is focused on the notion of the struggle of the soul (66).

Further on, an extension of the care of the self comes about that is no longer only associated with political activity, but as a permanent activity that enables the subject "to get prepared for a certain complete achievement of life. This achievement is complete at the moment just prior to death - of old age as completion - is an inversion of the traditional Greek values on youth.” Foucault thus associates an activity of political preparation with the realization of life up until the moment of death. This combination of ethics, aesthetics and politics is undoubtedly one of the distinguishing features of this later Foucault.

7 Homosexual love, which, according to Foucault, is behind the origin of Christian monasticism. 
Cura sui is, at its origin, a verbal and dialectical activity, in which the subject is shaped through norms learned by memory. In Alcibiades, the soul maintains a dialogue with itself through memory as a method for discovering the truth in the soul. This relationship with memory and truth, however, would vary later. Firstly, the dialogue as pedagogical method disappears, and silence becomes more and more important (Foucault says that, in Pythagoran culture, the disciples had to stay silent for five years, as a pedagogical rule). From dialectic culture we move on to the culture of silence and the art of listening attains greater importance. It is the change between the Platonic dialogues and the imperial period: in the latter the dialectical structure disappears.

\subsubsection{Technologies of the Self in the Stoics}

In this transformation, the Stoics were responsible for some of the fundamental changes of direction of these techniques of training politicians in techniques of self-care in order to attain the happiness of everyone in all areas of life. The writings of the Stoic, Seneca, introduce a further change in the figurative use of language, ${ }^{8}$ which seems to situate the care of the self alongside administrative practices, as "self-examination is taking stock" (71). Seneca is a stock-taking administrator, not a judge of his past. For Seneca, the technologies of self do not try to discover truth in the subject, but to remember the truth, to recover a truth that has been forgotten (what he should have done). Moreover, Foucault says, the recalling of mistakes made during the day makes it possible to measure the distinction between what has been done and what ought to have been done:

the subject is not the operating ground for the process of deciphering but is the point where
rules of conduct come together in memory. The subject constitutes the intersection between
acts which have to be regulated and rules for what ought to be done. This is quite different
from the Platonic conception and from the Christian conception of conscience.

Similarly, the Stoics spiritualized the notion of anachoresis as retreat. The origin of the term had a broader meaning as the retreat of an army, the hiding of a slave who escapes from his master, or withdrawal into the country to escape the city. With the Stoics, the retreat into the country becomes a spiritual retreat into oneself (a mnemotechnical formula) (72).

8 He seems to use juridical language, and it appears that the self is judge and accused at the same time. Seneca is the judge and prosecutes the self in such a way that the examination is a kind of trial. But in reality it is closer to administrative practices. 
As well as the letters to friends as revelation of the self, the examination of self and conscience, including a recollection of what has been done, of what ought to have been done and of the comparison between the two, Foucault also points out another technique of self in the Stoics: askēsis. Yet askesis does not have a revelation of the secret of the self in its origin either, but a remembering. The Stoics founded their technologies of the self in remembrance, in the recounting of experiences as a taking stock (alluding to Seneca's administrative language). For Plato, one should discover truth within oneself. For the Stoics, the truth is not in oneself but in the logoi, in the rules, in the teaching of the masters. One memorizes what one has listened to, converting the statements one has heard into rules of conduct. The Stoics recollect in order to review what they have done and what they should have done, with regard to the rule.

\subsubsection{Technologies of the Self in Early Christianity}

In early Christianity, ${ }^{9}$ ascetism refers to a certain renunciation of the self and of reality because most of the time your self is a part of that reality you have to renounce in order to get access to another level of reality. This desire to attain the renunciation of the self distinguishes Christian asceticism (73). While in the tradition inherited from Stoicism, askesis does not mean renunciation, but the progressive consideration of self, or mastery over oneself, obtained not through the renunciation of reality but through the acquisition and assimilation of truth, its goal is access to the reality of this world. The Greek term is paraskeuazõ (to get prepared), and it refers to a set of practices through which one can acquire, assimilate, and transform truth into a permanent principle of action. It is a process toward a greater degree of subjectivity. Thus, aletheia becomes ethos (or acts of truth as alethurgia).

The main characteristics of Greek askesis include two types of exercises that test preparedness for the event itself: melete and gymnasia. Melete means meditation (it has the same root as epimelesthai), and consists of practicing a series of memorized responses and reactivating those responses, by placing oneself in a situation where one can imagine how one would react ("suppose that ..."): "imagining the articulation of possible events to test how you would react that's meditation" (75). At the other extreme is gymnasia (to train oneself): while meditatio is an experience of imagination, gymnasia is training in a real situation, even though it may have been artificially induced (sexual abstinence, physical

9 Foucault finds the the origin of biopolitics and of our governability in early Christianity. Our government is based on an intrinsic relation between government and truth. 
privation, as well as other rituals of purification). In the culture of the Stoics, it comprises carrying out an examination of the independence of the individual with respect to the external world (very tough sports activities, mortification of the flesh to convince oneself that poverty is not an evil, and so on). Between the two extremes, melete and gymnasia, there is a whole series of intermediate possibilities, the purpose of which is the "control of representations, not the deciphering of truth" (78). Foucault find examples of these exercises in authors such as Epictetus and Cassian, for whom meditation is a type of permanent selfexamination, in which everyone must be their own censor. Here, "the meditation on death is the culmination of all these exercises" (78).

To letters, the examination of conscience and askesis, Foucault added the interpretation of dreams. ${ }^{10}$ But of all the technologies of the self that Christianity adapts from the Graeco-Roman era, the principal one is a type of game of truth. These techniques come about in the transition from pagan to Christian culture, in order to understand the continuities and discontinuities.

Christianity is a religion of salvation, which should lead the individual from one reality to another, for which a transformation of the self should occur in order to access the truth. And this access to the truth cannot be conceived of without self-knowledge. For Christianity, this entails the need to accept another form of truth different from that of faith: each person must know who they are - to try to know what is happening inside themselves, and to allow private or public witness against themselves. The relation between the obligations of faith and with oneself enable the purification of the soul. I quote: "Purity of the soul is the consequence of self-knowledge and a condition for understanding the text; in Augustine: Quis facit vertatem (to make truth in oneself, to get access to the light)" (80).

The early Christians had other technologies to discover and decipher the truth about the self, before penitence and confession. The modes of recognizing the truth about oneself were exomologesis and exagoreusis.

On the one hand, "recognition of fact", exomologesis, for Christians meant to publicly recognize their Christian faith was a ritual of recognition of themselves

10 It was a very popular practice, but the only surviving texts are The Interpretation of Dreams by Artidemidorus (2nd century C.E.) and two other documents: that by Synesius of Cyrene, from the fourth century, who believed that everyone should interpret their own dreams, for which "one had to record what happened every day, both the life of the day and the life of the night" (79); and the Sacred Discourses by Aelius Aristides, written in the second century, who believed that in the interpretation of dreams we receive advice from the gods about remedies for illness: the care of the body (79). The matrix of these discourses is the ritual inscription of praises to the gods that have healed one. 
as sinner and penitent. The individual was thus marked forever and could neither marry nor be ordained as a priest. Exomologesis is not a verbal behavior but the "dramatic recognition of one's status as a penitent”. Quote: “To prove suffering, to show shame, to make visible humility and exhibit modesty - these are the main features of punishment" (84). Thus a shift is produced from the forms of verbalization to the forms of dramatization of the self, it is the beginning of what Foucault called "the theatre of truth" ${ }^{11}$ Furthermore, this dramatization, which lasted until the fifteenth and sixteenth centuries, means a transformation of the nominal relation with the truth to one that was dramatic and public; whereas for the Stoics, as we have seen with Seneca, this whole process was private. ${ }^{12}$

Their function was a form of erasing the sin and restoring the purity acquired by baptism. This was the paradox: it erases the sin and it reveals the sinner. Exposé is the heart of exomologesis. Three models were used in order to explain the paradox of erasing and disclosing: the medical model (one must show one's wounds in order to be cured); the tribunal model of judgement (confession will help in the penance); but the most used was the model of death, martyrdom and torture. The theories and practices of penance were elaborated around the problem of the person who prefers to die rather than to compromise or abandon the faith: the martyr is the penitent (85). And penitence is precisely the consequence of the change, of the break with oneself, with the past and the world:

It's a way to show that you are able to renounce life and self, to show that you can face and accept death. Penitence of sin doesn't have as its target the establishing of an identity but serves instead to mark the refusal of the self, the breaking away from self: Ego non sum, ego. This formula is at the heart of publicatio sui. It represents a break with one's past identity. [...] Self-revelation is at the same time self-destruction.

As early as the fourth century we find a very different technology for discovering the self: exagoreusis, reminiscent of the verbalizing exercises related to a teacher/ master of the pagan philosophical schools. Here Foucault points out how various Stoic technologies of the self have been transferred to Christian spiritual techniques.

In John Chrysostom, we find an example of self-examination with the same form and the same administrative nature as that described by Seneca in De Ira.

\footnotetext{
11 "The subject is not the operating ground for the process of deciphering but is the point where rules of conduct come together in memory. The subject constitutes the intersection between acts which have to be regulated and rules for what ought to be done. This is quite different from the Platonic conception and from the Christian conception of conscience" (72).

12 The relation with disciplinary power is evident, and its theatrical nature recalls even the panopticon.
} 
But this self-examination with administrative language is scarce in Christian literature. The practice of self-examination in Seneca is based on the capacity of the master to guide the disciple toward a happy and autonomous life through good advice, and it was carried out for a limited period. But Christian obedience differs from Graeco-Roman obedience: it is total and permanent obedience. John Cassian wrote: "Everything the monk does without the permission of his master constitutes a theft." The master's control is an end in itself and not a final state of autonomy. "It is a sacrifice of the self, of the subject's own will. This is the new technology of the self" (88). The monk must have the permission of his master to do anything, even to die. There is not a single moment when the monk can be autonomous. The self must construct itself through obedience. This technology is not based on the remembrance of the past but on the continuous vigilance of the present. This examination of the present is based on contemplation as opposed to mobility of spirit, a mobility that is considered as weakness: "The scrutiny of conscience consists of trying to immobilize consciousness, to eliminate movements of the spirit that divert one from God", and passes through the suppression of desire, which distances from God. "The scrutiny is based on the idea of a secret concupiscence" (90). That desire that must be controlled is action itself as double force, which interrelates life drive and death drive. Here, however, a strict death drive is developed. ${ }^{13}$

Exagoreusis was practised until the seventeenth century and the inauguration of penance in the thirteenth century was an important step in its rise. According to Foucault, the latter becomes more important. From the eighteenth century to the present, the techniques of verbalization have been reinserted without renunciation of the self but to constitute, positively, a new self. To use these techniques without renouncing oneself constitutes, for Foucault, a decisive break (94).

13 There are, therefore, three principal types of self-examination: that which refers to thoughts (Cartesian), that which deals with the relation between thoughts and rules (Senecan), and that which establishes a relation between the hidden thought and interior impurity. At this moment hermeneutical Christianity of the self begins, with its deciphering of hidden thoughts and the establishment of confession: we can only discriminate between good and evil thoughts through the confession, giving ourselves over to being counselled by the master. However, the evil is hidden and unstated, which is why its verbalization will not be easy: confession is a mark of truth, even though the price of verbal expression was to turn everything that could not be expressed into a $\sin$ (93). The first is exomologesis, or dramatic expression of the situation of the penitent as sinner (martyrdom, "In the Penal Colony"). Second is what has been called exagoreusis, an analytical and continual verbalization of the thoughts carried out in the relation of complete and utter obedience to another. "This relation is modelled on the renunciation of one's own will and of one's own self" (93). 
Lastly, we can reach the following conclusions. First, the foremost Greek technologies of self did not entail a rejection of subjectivity itself but, rather, the care of self had political ends, more specifically democratic, for the training of young politicians who needed to care for themselves in order to be capable, subsequently, of the care of others. The government of self and the government of others went hand in hand. Those first technologies of cura sui took on a care for the soul and the body, proof of which are the letters that the disciples addressed to their masters.

On the other hand, the care of self showed subjectivity as a dynamic process and not as a hermeneutics of the hidden, as would later occur in early Christianity. The relation between subject and truth is constituted in opposite ways in GraecoRoman culture and in early Christianity: I have not been able to develop here the relations between truth as concealment/disclosure in Christianity and truth as action, as parrhesia. But it is undoubtedly one of the fundamental areas on which Foucault worked a few months after the Vermont lectures. Yet the continuity between parrhesia and Greek cura sui is evident, both being at the basis of the development of Athenian democracy, and upon which Foucault elaborated on numerous occasions.

Regarding the relation between desire and the death drive, one of the most important features of the definition of the subject in Foucault, as Judith Butler has so convincingly shown in her recent work, is that the subject cannot be radically freed from the mechanisms of power. The subject is constituted as subjection and liberation, at the same time. There is an active negativity at the basis of Foucauldian ethics: it is due to the death drive of the parrhesiast that he/she is capable of truth-telling, of confronting power. Like Freud, Foucault thinks of desire traversed by the death drive. But Foucault's most interesting contribution is that, precisely through action, the subject takes on the death drive as ethical and communal production (from negativity to virtuality). The most evident model, which Foucault turned to many times, is that of Socrates, who, as parrhesiast, produces a verbal truth (truth-telling) that combines criticism and construction for the government of others. Let us remember that criticism is, in itself, described by Foucault as a secondary and negative activity that is applied upon other discourse, whether political, literary, philosophical, etcetera ("What is Critique?"). The will in Foucault combines desire and the negativity of parrhesia. The action of speaking the truth concerns an awareness of putting oneself in danger, like running the risk of getting lost. But this is, at the same time, the only option that the ethical subject has of recognizing himself/herself as a political being: action as criticism (the logic of Sade).

Conversely, in his last lectures Foucault examines the figure of the parrhesiast who manages, in his/her subjective decision-making, in his/her ethical action, to 
make the death drive the production of a communal, ethical and political event. It is, indubitably, the basis of the concept of resistance that Foucault formulated in the 1970s. We witness the opposition between a "fascination for the death drive" that the reciprocal tangle of Law and desire entails in early Christianity. In the words of Žižek, "in which the 'dead' letter of the Law perverts my very lifeenjoyment, turning it into a fascination with death; [...] is what [Saint] Paul considers 'the way of the flesh' (as opposed to 'the way of the Spirit'). 'Flesh' includes both what is against the Law and the excessive self-torturing, self-mortifying, morbid fascination with the flesh that is begotten by the Law"14 (Žižek, The Ticklish Subject: The Absent Centre of Political Ontology, 150).

\subsection{Subject to the "intemperie". Readings of Foucault in the 21st Century}

For Foucault, modernity is associated, on the one hand, with a concept of teleological history that is detached from the weight of tradition, and, on the other hand, with a concept of an autonomous and sovereign subject. This is why, if one wishes to analyze the critique of the concept of the modern subject in Foucault, one cannot avoid the discourse on history and vice versa. In 1971, Foucault declared as much in Nietzsche, Genealogy, History:

\footnotetext{
History becomes "effective" to the degree that it introduces discontinuity into our very beingas it divides our emotions, dramatizes our instincts, multiplies our body and sets it against itself. "Effective" history deprives the self of the reassuring stability of life and nature, and it will not permit itself to be transported by a voiceless obstinacy toward a millennial ending.
}

With this, Foucault underlines the dialogue between what were to be two of the most important issues in his work: the critique of the concept of the modern subject and his proposal of a genealogy of history as an alternative to teleological history. Modern subjectivity, which Foucault confronted in his early "death of man", stressed the need for a positive deconstruction of the concept of subject. He proposed thinking of the hidden face of the modern subject as a subject of desire, for which he traced a genealogy of irregular subjects, namely, of those subjects who had remained outside modern universality. These subjects, who make up the outside of the modern subject, are characterized at the same time by modes of narrating that are very different from those of the story as bios (it "deprives the self of the reassuring stability of life and nature"). We see the most

14 We can find an example in the torture device in Kafka's "A Hunger Artist". 
evident example in the chapter devoted to the "Sade Lectures" that Foucault gave at the University of Buffalo, in which Foucault sets forth a non-attributive and discontinuous mode of being that reveals the relationship between the death of man and the death of God, and that new, non-teleological concept of history.

In recent years, the work of Wendy Brown has continued the critique of modernity from the Foucauldian perspective. In Politics Out of History (2001), she attempts "an understanding of liberal universalism as not simply containing a history of excluded others but as having a specific normative content - heterosexual and patriarchal families, capital, and "property in whiteness"' (9). According to Brown, liberalism therefore presupposes sovereign individuals and states to be a unit of analysis and as subjects of action. Sovereign individuals are considered based on their autonomy to define and satisfy their needs, and, principally, based on whether they are capable of taking charge of their acts, so that a "power conceived as generated and directed from within the entity itself" (10) can be ensured. But Foucauldian analyses of power bring into question whether the conviction that we are the ones who plan and pursue our ends can be maintained when we are so clearly, in part, the effects of those powers:

How the disruption of the status of the universal in liberalism undermines the progress narrative is captured in a general questioning (if not outright rejection) of assimilationist and integrationist formulations of social change and the adoption of identity-based justice claims and local nationalisms.

For Brown, as for Foucault, the nexus between subjectivity and history is narrative, stories. Thus the questioning of this supposed modern universality erodes the reliability of its classic narrative about what its legitimization is based upon. This tale that liberalism tells defines an "outside". And this outside, which legitimized liberalism, is represented by opposing social systems such as feudalism understood as its past - or Communism in the twentieth century. Yet, Brown argues, recent years have shown that feudalism remains in the subject: the little independence between state and market, the disappearance of the Communist models, but above all, the bourgeois character of the "universals".

From this perspective, a new story of subjectivity has become necessary, one that overcomes the narrative limits of modernity - a narrative model that overcomes the limits of the bios: those of the life of nature (birth) and death as end. Apparently, this story of a subject that spreads out from before their very birth and beyond their very death, that breaks the attribution of a body, a life and a story, would lack verisimilitude. This is because, from Aristotle on, the story that was told had to be a living organism. Similarly, the work of Jacques Rancière has come to show the importance that the studies on fiction have for the analysis of 
contemporary societies. Rancière's thought complements Foucault's on fiction where it positions itself facing the challenge of thinking fiction as opposed to the "real”, because, since Guy Debord by way of Althusser, "ideology has spread its dominion massively over all the real. The real is largely confused with ideology" (Althusser, Machiavelli and Us, 17). Fiction is defined by both thinkers not in terms of invention but as a material negativity that makes it possible to see/hear a virtual being there, as an opening to a past that extends its consequences onto the present and a future that likewise entails its demands. Fiction, thus defined, is the model of resistance that Brown appeals to for the new narrativity.

In order to consider the proposal of a story of self that shifts the limits of modern rationality, I will analyze two models passed down from the Foucauldian project: the impossible models of Judith Butler in Senses of the Subject (2015) and Giorgio Agamben in Language and Death (2006 [1982]) and The Fire and the Tale (2017 [2014]). These propositions are a break from the classical organic model, as both challenge the limits of the story as bios and question the principle of the tale's rationality, from a hermeneutics of the subject that is enunciated to itself and to others.

In the basis of the hermeneutics of the subject that Butler propounds in Senses of the Subject, we can find a retroactive hermeneutics of the literary text. Butler states that the comprehension of the subject (subjected subjectivity) is based on the literary models that present their characters telling of their own birth, such as the "I Am Born" of David Copperfield. This is an "impossible" perspective, alien to the discourse that is governed by the cause-effect dialectic. The other impossible literary perspective is that of a subject of enunciation who speaks from death itself, such as in Julio Cortázar's "Las babas del diablo". This is the process of composition of a subject not "for-death" but that takes an undefined plural voice.

For this deconstruction of the liberal subject and its story, it is necessary to begin with Foucault's concept of fiction. As has already been seen, in "L'ArrièreFable" (1966), Foucault gives fiction a fundamental character as the mode of articulation of all discourse, the nature of which is historical, which I have referred to as the "social-fictional pact". The concept of truth-telling, therefore, shifted to being historical and cultural, as that which a society is willing to accept as credible and not structural. And the modes of truth-telling, or veridiction, in this early text already had a historical and fictional nature. He would develop this approach in the later years of his research. In the Louvain lectures, "Wrong-Doing, Truth-Telling" (1981), he fully confronts the question of how a mode of veridiction (Wahrsagen) could come about in history, and under what conditions. It is a question of defining the modes of veridiction in their plurality, exploring the forms of obligation by which each one of these modes links to the subject of truthful speech, specifying the areas they are applied to and the domains of objects that they reveal, and, 
lastly, the relations, connections and interferences that are established between them. In short, it is a historical politics of truth or a political history of veridictions.

\subsubsection{Before their Own Birth: The Hermeneutics of the Subject}

In The Psychic Life of Power, Butler reinterpreted Foucault's processes of subjectivation with regard to power and resistance through a subject that is constituted in origin as a fold, a turning on itself. Here Butler defined the subject as a consciousness that is determined by a relation of power, dependence, or subjugation. But, according to the author, this origin is supressed. Thus subjectivity is defined as a process in which otherness affects and precedes the enunciation of the "self". Therefore, in the definition of subject that she makes in this work, otherness, as the drive of the power that subjects, forms the origin itself of subjectivity as psychic reality. Hence the self is already, as of always, also the other of the community that founds it, in its ethical dimension: the subject is constituted, therefore, as a fold, and its nature is relational:

The form this power takes is relentlessly marked by a figure of turning, a turning back upon oneself or even a turning on oneself. (...) The turn appears to function as a tropological inauguration of the subject, a founding moment whose ontological status remains permanently uncertain.

(Butler, The psychic life of power, 4)

According to Butler, this tropological dilemma of the subject is that of the trope as a fold, in its original Greek definition. ${ }^{15}$ Continuing with the question of the forming of the subject, this relation of the subject with its foundational dependence would be thoroughly repressed - that is, the subject emerges at the same time as the unconscious. This would mean that the subordination and formation of the subject in Foucault would take on psychoanalytic value in Butler's reading: in order for the subject to emerge, the primary forms of this bond must arise and at the same time be denied. In other words, "the 'I' as predicated upon that

15 There is not enough space here to go into detail on this subject, but it is worth noting about this tropological configuration of the subject the paradox or turn that lies at the very origin of the modern novel. Several authors have highlighted this relation, including Julia Kristeva, who considers it a diagnostic trait of the modern novel that was already evident in Bakhtinian dialogism. More recently, we can find it in Jacques Rancière's definition of the politics of literature as contradiction (The Politics of Literature, 2011). Similarly, in Poéticas de la enfermedad en la novela moderna [Poetics of Illness in the Modern Novel] (2015), María Victoria Utrera analyses and gives many examples of the key role that the turn/fold occupies in the modern novel, including Dostoevsky, Maupassant, Poe and Hoffman. 
foreclosure, grounded in" the love-subordination that founded it. ${ }^{16}$ Therefore, both for Foucault and for Butler, an analysis of power is inseparable from a history of subjectivities as resistance, ${ }^{17}$ and this through the discursive constitution of subjectivity. For Butler, ${ }^{18}$ whether through interpellation in Althusser's sense, or through discursive productivity, as per Foucault, “'subjection' signifies the process of becoming subordinated by power as well as the process of becoming a subject" (2). So according to Butler, the production of the discursive subject of Foucault has as a precedent Althusser's theory of interpellation.

Foucault's last lectures and seminars were published from 2004 to 2015. Following the new ideas from this previously unpublished work, Butler, in Giving an Account of Oneself, corrects the rigidity of the Nietzschean model of the configuration of the subject by power. The "rigidity" refers to what Butler calls the "punitive scene of inauguration for the subject" (Giving an Account of Oneself, 15), which Foucault had stated in the first volume of History of Sexuality but which he himself had corrected in his later lectures. Fundamentally, however, he returns to an issue that he had discussed there, of knowing whether we are somehow determined before being born by that other that precedes us and which is precisely what makes our configuration as subjects possible - and tying it in with Brown's concern in Politcs Out of History: how do we talk about ethical responsibility? That is to say, referring to Butler's book title, how can a subject give an account of oneself? For Butler, the subject is not constructed ex nihilo but neither does the dispossession of the self mean that the subjective foundation of ethics has been lost. On the contrary, "it may well be the condition for moral inquiry, the condition under which morality itself emerges" (8). Therefore, ethics will be inseparably bound up with the subject and the social configuration that precedes it and constitutes it at the same time.

The concept of ethics upon which she bases her argument also follows Adorno and other recent authors such as Rancière, for whom the collective ethos cannot be homogeneous and unitary. When the collective ethos is not shared by the whole and yet is shown under the appearance of a false unity, it instrumentalizes violence to maintain the appearance of its collective nature. The ethos is violent when it becomes an anachronism and denies the rights of the individual (Butler, Giving an Account of Oneself, 5). At the same time, ethics

16 What Butler calls passionate attachments (6), and which owes a debt to amor fati as Nietzsche defined it in Aphorism 276 of The Gay Science: simultaneously subjection and desire.

17 Thinking of the lives of infamous men as modes of dissident forms of being.

18 Butler's concept also functions with a similar logic as the Freudian concept of Umheimlich: that of the disturbing that has been repressed which coexists with the familiar. Because it is the repression that enables the superposition of opposites, and their coexistence. 
cannot be so for the individual external to the collective. Ultimately, for Butler, the very constitution of the subject is social, dialogic and ethical:

Yet there is no "I" that can fully stand apart from the social conditions of its emergence, no "I" that is not implicated in a set of conditioning moral norms, which, being norms, have a social character that exceeds a purely personal or idiosyncratic meaning.

The "I" does not stand apart from the prevailing matrix of ethical norms and conflicting moral frameworks. In an important sense, this matrix is also the condition for the emergence of the "I," even though the "I" is not causally induced by those norms.

(Giving an Account of Oneself, 7)

According to Butler, Foucault distances himself from his view in the first volume of The History of Sexuality and alters his theory of discursive construction.

The subject is no simple effect or function of a prior form of rationality, but neither does reflexivity assume a single structure. Moreover, when the subject becomes an object for itself, it also misses something of itself; this occlusion is constitutive of the process of reflexivity. [...] Something is sacrificed, lost, or at least spent or given up at the moment in which the subject makes himself into an object of possible knowledge.

(Giving an Account of Oneself, 120)

For this reason, Foucault asks the question: "How much does it cost the subject to be able to tell the truth about itself?" When the human subject applies forms of rationality to itself, this self-application is costly. To which Butler adds a new problem: how can the subject overcome this vicious circle between power and subordination?

For Butler it is the story that enables us to overcome this impasse. She considers that the subject always gives an account of itself insofar as it is interpellated by another to do so. Every one of us gives an account of ourselves when interpellated and interrogated about our actions. The giving an account then acquires narrative form. Hence, the mode by which it is established whether the self was or not the cause of the suffering of another has a dialogic narrative structure. The story provides a persuasive medium by virtue of which the causal agency of the self can be understood. In this sense, writes Butler, "narrative capacity constitutes a precondition for giving an account of oneself and assuming responsibility for one's actions through that means" (12). But what would the story be like of a subject that has to take on what has formed it but in which it has not participated voluntarily?

The ethical subject that tries to give an account of itself is therefore faced with two limits. On one hand, it cannot give an account of what precedes it and what, nevertheless, forms it, because "this self is already implicated in a social temporality that exceeds its own capacities for narration" (8). And, on the other 
hand, the modes in which the subject gives an account of itself have a cost, insofar as the narrative is subjected to some forms of historical rationality: ${ }^{19}$

There will be a reflexive action of a subject, and this action will be occasioned by the very rationality to which it attempts to conform or, at least, with which it negotiates. This form of rationality will foreclose others, so that one will become knowable to oneself only within the terms of a given rationality, historically conditioned, leaving open and unaddressed what other ways there may have been, or may well yet be, in the course of history.

Both limits, thus stated, would come imposed by a narrativity determined by a temporality, which is a rationality, in which the subject is formed and gives an account of itself. They would appear, therefore, as structural limits or a priori the discursive nature that would determine not only the subject in its daily events, but also in its ethical dimension. Butler thus proposes confronting the forms of historical rationality that have conditioned and subjected the narrative of the self since Aristotle (because, as I have explained, to tell the story of the self is at the same time making history itself). For this, Butler applies the Foucauldian concept of fiction and fable to the configuration of the story of the self - which is, remember, the ethical subject's mode of giving an account of itself. Butler shows that both limits depend on the same classical causal logic. Faced with the temporal limit, as an impasse between the story of the self and the formation of the subject, she now proposes not succumbing to silence but to "accept this belatedness and proceed in a narrative fashion that marks the paradoxical condition of trying to relate something about my formation that is prior to my own narrative capacity and that, in fact, brings that narrative capacity about" (Giving an Account of Oneself, 2). In other words, Butler proposes accepting a narrative model that enables us to tell and take authorship of the story that precedes us, before our own birth: the retrospective story.

\subsubsection{The Retroactive Hermeneutics of the Subject that Narrates Itself}

In Senses of the Subject, published in 2015, ten years after Giving an Account of Oneself, Butler's aim was to expand her work on the formation process of the

19 It could be said, following Judith Revel's hermeneutics of discontinuity (2014), that Foucault had already answered this question in the 1970s, particularly in his 1973 study, I, Pierre Riviere, having slaughtered my mother, my sister, and my brother: A Case of Parricide in the 19th Century, which involves an "impossible" mode of narration, one that resists the framework of modern rationality. 
subject and its capacity to give an account of itself. The great novelty of this book, however, is the text that precedes it, Foucault's only unpublished work, and which would have been Butler's motivation in her new study. Here, she herself gives an account of a constant concern in her work: that which deals with the formation of the subject. But this same text introduces something new in that it aims to reformulate the two limits of the narrativity of the ethical subject that are not found in her earlier texts: the temporal limit and that of the discursive modes of rationality.

Butler states that both limits, however, depend on the same classical causal logic. Concerning the temporal limit, an impasse between the story of self and the formation of the subject, she now proposes that we do not succumb to the silence but "accept this belatedness and proceed in a narrative fashion that marks the paradoxical condition of trying to relate something about my formation that is prior to my own narrative capacity and that, in fact, brings that narrative capacity about" (Senses of the subject, 2). In other words, Butler proposes accepting a narrative model that enables us to narrate ourselves before our own emergence. For a subject to give an account of itself, it needs to position itself retrospectively, but this "casts doubt on whether or not I can describe this situation at all, since strictly speaking I was not present for the process, and I myself seem to be one of its various effects” (2).

This belatedness in the story of oneself is, according to Butler, what Freud calls Nachträglichkeit (deferred action or retroaction). In "Inhibitions, Symptoms and Anxiety" (1926), Freud defines it as those mnemic impressions or traces that might not acquire all their meaning, all their effect, until a time subsequent to their initial recording. This is therefore a concept of retrospective temporality, which combines the narration with historical perspective. The Freudian deferred action also has a fundamental hermeneutic value that Butler uses for her critique of this temporal limit of discourse, insofar as rereading and the capacity of reading as resignification and appropriation of the past. ${ }^{20}$ As Eickhoff ("On Nachträglichkeit”, 2006) explains, Nachträglichkeit is a circular hermeneutic concept that makes it possible to make complementary readings in both directions: from the present to the past and vice versa. So an event in the present would have an influence on certain contents of the memory, modifying them and giving them new significance. These contents of the memory would at the same time become newly activated and have new repercussions on the present and the future. The reading model that Butler puts forward also keeps a close relation with the modes of Foucault's archival reading (1970) and with what Judith Revel

20 Butler removes the concept of traumatic content that Freud gives this belated and traumatic understanding. 
(2010) has called "discontinuity". These models of reading put an emphasis on a discursivity that is neither linear nor causal. These authors defend a model of discontinuous discourse that escapes the principle of causality ${ }^{21}$ and whose reading can be, as Judith Revel puts it, "reversible".22

The discursive model that allows Butler to think against this belatedness is literature, because, as Foucault states in "Literature and Language" (1966), literature is founded on an excess of language, not on silence or the ineffable. Butler reflects on that narrative sequence of an "I" that emerges at the time that it enunciated, starting with a literary model that gives an account of that scenario that she notes as impossible. This is the opening of Dickens's David Copperfield, a novel in which the narrator speaks with extraordinary precision about the details of the ordinary life that preceded and included his own birth. Although the story begins by mentioning that the history has been told to him and that he believes it to have been thus, the way in which the story continues, it seems that he himself is the only one who has the authority to tell of his own birth. Moreover, it is as if he had been present in this "impossible scene". Butler warns that narrative authority does not need to be at the scene. It only requires one to be able to reconstruct the scene from a position of non-presence in a believable way, or that an unbelievable narration be convincing for its own reasons.

With this statement, Butler alludes directly to the Aristotelian concepts of verisimilitude, mimesis and fable, because they are at the basis of the limits of the narration of a subject who has to give an account of itself as an ethical and responsible subject. The limits of giving an account of oneself are limits of a specific type of narration, as defined Aristotle. That Aristotle admitted the capacity of knowledge to the Poetics meant placing limits on it that were those of metaphysics. Therefore, the concepts that he defines in Poetics, and also in part in Rhetoric, are founded on the principles of this metaphysics, insofar as mimesis is of reality and for the comprehension of reality it is necessary, according to Aristotle, to obey the laws of causality. And this, in turn, determines what is admitted as true. In the literary text, this causal organization defines the fable, which determines what is truthful in the text. But remember that what is truthful was identified with what is probable, due to that status of poiesis being closer to the philosophy that speaks of what might happen than to history, which speaks of what has happened. Therefore, Aristotle concluded, poiesis, like philosophy, was more universal. In this way, the limits of narration were

21 As in Nietzsche's discontinuous chain: discourses are susceptible to changing their meanings and can take on others for which they were not at first thought.

22 Revel bases her reading of the revolutionary possibility of history on this. 
determined by a progressive temporality that established a structure determined by a causal logic of events (beginning, middle, end).

Having called into question the limits of classical narration, Butler confronts progressive temporality, the retroactive temporality of Freud, and causal logic, the belatedness between the formation process of the subject and their enunciation as "I speak". This narrativity from an impossible position, says Butler, helps us to understand the theory of subject formation:

Could it be that the narrative dimension of the theory of subject formation is impossible, yet necessary, inevitably belated, especially when the task is to discern how the subject is initially animated by what affects it and how these transitive processes are reiterated in the animated life that follows? If we want to talk about these matters, we have to agree to occupy an impossible position, one that, perhaps, repeats the impossibility of the condition we seek to describe.

(Senses of the subject, 4)

Thus, the author takes Aristotle's concept of verisimilitude one step further, to the concept of virtuality, which combines in itself what is real and what is possible. For Butler, as also for Foucault and Deleuze, a narration contains a series of virtuals or possibles, which are updated following each historical moment (Foucault) or each plane of the particular reality (Deleuze). The virtual is realized in a state of things and of what is lived that makes it possible. This means, according to Butler, that these impossible models of narration offer the possibility for the subject to take control of his story, even of the part that preceded their linguistic consciousness:

What he relates may or may not be true, but it hardly matters, once we understand that the story he reaches for says something about his authorial ambitions and desires, clearly meant to counter and displace the infant's passivity and the lack of motor control, a resistance perhaps to needing to be in the hands of those he never chose.

Butler interprets this scene of extraordinary self-understanding in terms of a narrative resistance: the subject resists the power relations that formed him through an unbelievable but verisimilar narration. Beyond the logic of the Aristotelian fable, Deleuzian virtuality (2007) and Butler's analysis, they are anchored in the logic of the event.

One of the fundamental aspects of this theory is that Butler does not assert that what happens in literary works such as these has a parallel in the theory of subject formation. Rather, she says that narrative gestures such as these find their place close to any theory of subject formation (5). This narrative dimension of Butler's theory of subject formation is based on a hermeneutics of the subject that is a hermeneutics of narration, inextricably tied to literature. This hermeneutics of 
the virtual and belatedness is necessary, above all when the task is to discern, Butler says, how the subject is initially animated by what affects it and how "the contours of an ethical relationship emerge from this ongoing paradox of subject formation" (6). If we wish to talk about it, Butler says, we must accept occupying the impossible position. To say that this is impossible does not mean that it cannot be done, only that we cannot find a way back from the constraints of adult life, except by asking how those incipient passages remain with us, recurring again and again. To say that I am affected before even becoming "I" means confounding both temporalities through language. And Dickens's impossible model allows Butler to enunciate an affective resistance that the literary text realizes in its letting see what had habitually belonged to the unconscious.

\subsubsection{An Aesthetics of Existence as Ethics of the Understanding of Self}

We return to the question that Butler asked in Giving an Account of Oneself: how can a subject that has already been conditioned before its own birth make itself responsible for its own acts? Ten years later, she has placed at the centre of the debate the role that literature occupies in the narration the subject itself gives. As we have seen, in Senses of the Subject Butler proposes a retroactive hermeneutics of the subject that narrates to the self. When the omniscient narrator of David Copperfield recounts his own birth, he "takes authorship" of what had preceded him and formed him. The opening chapter of Dickens's novel, under the title "I Am Born", uses a narrative strategy that Butler interprets as a double irony ("will this narrator be authored, or will he author himself?"), for the narrator is a construction of the author and so counts on his authorship even as he poses that question, "suggesting that he might be able to leap out of the text that supports his fictional existence" (3).

The narrator, from a position of non-presence in a verisimilar way, "takes authorship" of their own story, giving it a significance in that they recount their particular understanding of themselves (3). In this "taking authorship" of their own story, the narrator intervenes, takes on and transforms the passivity of their story, which could not be deleted but could be retroactively reinterpreted. The subject thus assumes what forms it collectively and affectively, which is ultimately the ethical configuration that gives birth to it as a subject. But this "taking authorship" does not entail a determinism of the subject but rather that, as Butler says, the capacity of transformation of the subject - the creation of oneself (poiesis) - cannot be undertaken outside of a mode of subjectivation or subjection (assujettissement). Consequently, self-realization cannot take place in the absence of the norms that configure the possible forms a subject can adopt (Giving an account of oneself, 17). 
For this reason, Butler explains, the shift from a hermeneutics of the subject, which is given in the context of a set of norms that precede and exceed the subject, to an aesthetics of subjectivity must be made through critique. Following the arguments that Foucault made in his lecture, "What is Critique?", Butler states that the practice of critique would thus "expose the limits of the historical scheme of things, the epistemological and ontological horizon within which subjects come to be at all. To make oneself in such a way that one exposes those limits is precisely to engage in an aesthetics of the self that maintains a critical relation to existing norms" (17). This critique, she says, would provide the desubjugation of the subject within what Foucault called a "politics of truth".

Undoubtedly, the literary modes through which a subject can give an account of itself and include this tradition of a "politics of truth" are those that are formulated in the first person as omniscient narrator, as a confession, narrating their memories, in a diary, in letters, and so on. Such discursive strategies form part of the technologies of self, as technē of oneself or poiesis. But the truth of these texts, as Butler reminds us in Senses of the Subject, concerns less the reference than the use of discursive strategies that enable us to give an account of what forms us and precedes us, that is, of our birth as ethical and social beings. These are narrative strategies that, as has been explained, enable the subject to overcome the impasse between their conscious and discursive birth, and in which subjectivity was formed in a receptive way. It is therefore through the hermeneutics of the literary text that Butler definitively overcomes the discursive limits of the hermeneutics of the subject, which she had described in The Psychic Life of Power, and which impeded the subject from giving an account of itself and taking authorship of its own story: "Subjection consists precisely in this fundamental dependency on a discourse we never chose but that, paradoxically, initiates and sustains our agency" (The psychic life of power, 2).

As Butler explained, one gives an account of oneself insofar as one is interpellated and, in one's story, adopts the gesture that precedes and founds it. With this gesture, Butler assumes Walter Benjamin's thesis by which the subject makes an experience with the past that is unique. One takes responsibility for oneself when assuming and taking authorship of one's story in the narration of the self. Ultimately, these necessary narrative modes, although fantastical, make it possible to alter the status of truth of literature, which is not with a causal mimesis but with an ethical truth. 


\subsubsection{From the Outside to the Post-mortem Virtual Subject}

\section{a. The fold and the vortex: the relational subject}

The legacy of the hermeneutics of the subject and its relation with literature in later Foucault finds one of its most productive readings of the 21st century in Butler, and entails an overhaul of the interpretation made by Gilles Deleuze in his 1986 lectures on Foucault. In turn, the reading Deleuze made of Foucault's concept of subject finds another fundamental echo that is simultaneously conflicting and complementary, in Giorgio Agamben.

It is worth noting that Deleuze, Butler and Agamben all choose literary models to address the hermeneutics of the subject inherited from Foucault. It is precisely using Foucault's readings of literary texts that Butler's impossible literary model contrasts with Deleuze's oceanic literary model, given in his lectures on subjectivity in Foucault (La subjetivación. Curso sobre Foucault, 2015), out of which Agamben would develop his metaphorical concept of the subject as "vortex" (The fire and the tale, 2017). All three also make use of the concept of the subject as a fold, but taking different directions. If for Butler subjectivity is a fold of the other understood as the social (Levinas, Laplanche), in Deleuze, subjectivity is a fold of an impersonal exteriority, while in the case of Agamben, closer to the Deleuzian reading, it is an aquatic fold of the linguistic being, in the modes (mannerism) in which the substance relates with the modes in the historical future of language (The fire and the tale, 53).

In order to understand the different directions these readings take, we need to look at the contrast between the spatiality in which Deleuze's concept is developed, whereas in Butler it is developed around two temporalities: the belated, Nachträglichkeit-retroactive temporality, and another in which the subject distances itself, denies its attachment and projects itself in an autopoiesis. In Deleuze, the line ${ }^{23}$ of subjectivity breaks with the line of power toward the absolute outside as deterritorialized geography. The unconscious is similarly defined in both authors in a contrary way: for Butler, in the formation of subjectivity, the unconscious is formed out of an affective otherness, which is, at the same time, the origin of an ethics; in Deleuze's reading of Foucault, the unconscious is neutral because it only knows impersonals, indefinite articles, third persons, in other

23 Deleuze distinguishes three lines in Foucault: knowledge, power and subjectivity. Deleuze says that we must understand line of flight understood as an attempt to free and deterritorialize thought, but like all lines of flight it can be revolutionary or generate oppressive thought; the line of flight can produce insane, schizophrenic or paranoid geniuses. Thus the need for prudence, in order to avoid as much as possible setbacks and destruction (Deleuze, Subjetividad, 28). 
words, non-persons (Deleuze, Subjetividad, 11) and would be heir to Blanchot's idea of the impersonal. In Blanchot, furthermore, this third line would be the "one dies" which must be passed through, although the movement that pulls it from death is produced:

But that moment through which it has passed is not deleted, that moment remains. The line of the outside will always be marked by this deadly nature: the only way of escaping power is to cross the shallow stream... the shallow stream of death.

But what is this death that one can return from? Death in Blanchot is something very dangerous, it is to confront the void, "there, reason is lost" (29). That radical outside, the third line, as Deleuze calls it, is thus Unreason. The outside that forms the interiority (subjectivity as fold of the outside) confronts, according to Deleuze, a break line that is the radical outside - that is, death, madness, Unreason. Thus, Deleuze argues, the fold is necessary; otherwise one cannot live (29). In contrast, for Butler this confrontation is already there in the moment prior to the formation of all subjects, one step before (no more) the subject's beginning. Thus Butler overcomes Blanchot's Heideggerianism, which is the precedent to this concept (the outside as the neutral). It is not being for death, but the Freudian configuration of the subject as a deferral of understanding.

The literary model that Deleuze uses of the fold as a condition for life breaking with death is the oceanographic model: Moby Dick. Captain Ahab confronts the line of the outside, he passes from the other side, Deleuze says, but he has not made a fold, his vessel is broken. On all levels this, says Deleuze, concerns the river, the ship, the sea, and so on. Nevertheless, we find another literary text where the formation of the fold of the outside reaches a good harbour. This is the novel by Blanchot, Thomas the Obscure (1941), which shows this question in an almost explanatory way. I am particularly referring to the first chapter, where the process of the formation of the fold of the outside is described step by step.

1. The opening paragraph of the novel describes the formation of the line of the outside:

Thomas sat down and looked at the sea. He remained motionless for a time, as if he had come there to follow the movements of the other swimmers and, although the fog prevented him from seeing very far, he stayed there, obstinately, his eyes fixed on the bodies floating with difficulty. [...] The conviction that there was, in fact, no water at all made even his effort to swim into a frivolous exercise from which he drew nothing but discouragement. Perhaps he should only have had to get control of himself to drive away such thoughts, but his eye found nothing to cling to, and it seemed to him that he was staring into the void with the intention of finding help there.

(Blanchot, Thomas the Obscure, 7) 
2. The exit to the impersonal outside, or what Deleuze calls "confronting the one dies":

[...] As he swam, he pursued a sort of revery in which he confused himself with the sea. The intoxication of leaving himself, of slipping into the void, of dispersing himself in the thought of water, made him forget every discomfort.

3. The fold as the interiority of the outside:

[...] The illusion did not last. He was forced to roll from one side to the other, like a boat adrift, in the water which gave him a body to swim [...] he went on swimming as if, deep within the restored core of his being, he had discovered a new possibility [...] it was like an imaginary hollow which he entered because, before he was there, his imprint was there already. And so he made a last effort to fit completely inside. It was easy; he encountered no obstacles; he rejoined himself; he blended with himself, entering into this place which no one else could penetrate.

As has been seen, both in Deleuze and Butler the interpretation of Foucault's legacy of the process of subjectivation as a fold of the outside is undertaken through literary models. But although Deleuze explains that line of the outside as the "one dies" or the threat of Unreason, through what he comes to call "literary experiences" such as those of Hölderlin or Artaud, Butler meanwhile proposes a literary model that belongs to an ethics of discourses that precede and form ethical subjectivity. Agamben's reading, also formulated on the line of "one dies", is in dialogue with the concerns of Butler and Deleuze that I have expressed here. But I will particularly look at the reconfiguration of the relations between subjectivity and historical time, which could be seen as a mode of complementing that of Butler's.

\section{b. The "in-temperie" virtual subject}

Giorgio Agamben describes a subjectivity marked by the margin of the outside that forms the fold as "one dies", also concerned by the modes of legibility in the face of a lost origin, that is, in the face of the irremediable loss of an original meaning that could be re-established. Thus it can be argued that in the subject formation process not only does the story that precedes its own birth have an effect, determining in the subject a dialogic structure, but also as a subject conditioned by that other fictitious story that is the anticipation of death itself. Therefore, the process of subjectivation is supported on a double fictional base that enables it to give an account of itself insofar as the process of subjectivation is configured as transsubjective plurality in both directions. In other words, for Agamben the fold of the outside that frames the subject is neither the death nor the disappearance of the 
subject but rather its potentiality, since the inoperative time of certain death introduces a hiatus in the present as negativity and possibility.

Let us say, moreover, that both form part of the same hermeneutic gesture. As Eickhoff explains, Nachträglichkeit is a circular hermeneutic concept that makes it possible to make complementary readings in both directions: from the present to the past and vice versa. So a reading from the present would have an effect on certain contents of the memory, altering them and giving them new significance. These memory contents, in turn, would be newly activated and would have new repercussions in the present and the future.

But how can the relationship of literature with death be constituent action of the subject? To answer this question, let us look at two texts by Agamben: Language and Death. The Place of Negativity (2006 [1982]) and the more recent The Fire and the Tale (2017 [2014]). In the former, the Italian author tackles the relation that Western thought establishes between the subject, death and language from an ethical perspective but still immersed in a metaphysical discourse:

Both the "faculty" for language and the "faculty" for death, inasmuch as they open for humanity the most proper dwelling place, reveal and disclose this same dwelling place as always already permeated by and founded in negativity. Inasmuch as he is speaking and mortal, man is, in Hegel's words, the negative being who "is that which he is not and not that which he is" or, according to Heidegger, the "placeholder (platzhalter) of nothingness".

(Agamben, Language and death, xii)

The negativity of the subject, what it is and is not, proceeds from the fictitious experience of death as anticipation of its possibility: "This negativity is the basis for the possibility of the negativity of inauthentic Dasein in its falling (Verfallen); and as falling, every inauthentic Dasein factically is. Care itself, in its very essence, is permeated with negativity through and through [durch und liurch von Nichtigkeit durchsetzt]" (Language and death, 2). Let us consider, therefore, the political capacity of negativity that Agamben shows in Language and Death. In order to do so, we must turn to The Fire and the Tale. More than thirty years separate the two works (1982-2014), and Agamben's thinking on negativity acquires the political dimension I have referred to with Rancière and Foucault, which Agamben calls a "poetics - or politics - of inoperativity" (The Fire and the Tale, 50).

Agamben's question revolves around negativity as a "forgetting" of meaning, and as inoperativity of the work - always in potentiality as potentiality of no, Bartleby's "I would prefer not to" - the time of which is that of virtuality. This time is what permits the work to speak and be silent at the same time:

The genuinely philosophical element contained by a work - be it an artistic, scientific, or theoretical work - is its capacity to be developed; something that has remained - or has 
willingly been left - unspoken and that needs to be found and seized.

(The Fire and the Tale, 34)

As in Deleuze and Blanchot, this development of potentiality, Agamben writes, enables attaining an "impersonal zone of indifference". However, this impersonal and neutral zone has a genuinely political nature, insofar as in it "every proper name, every copyright, and every claim to originality fades away" (34). In this way, the pre-individual conditions that form subjectivity formed the interrelational and ethical nature of the subject; this negativity is, at the same time, the opening to the possibility of the subject and of a democracy of reading founded on a hermeneutics of the unfinished text. ${ }^{24}$ It is here that Agamben positions the Foucauldian project of the care of the self as "the way in which the individual constitutes himself as the moral subject of his own actions" (130), or "aesthetics of existence". Following Foucault, the subject is that ethical relation in itself and the creation of the self. Because the subject is by nature unfinished, only its total absence of substance enables the subject to be the object of its own work, in the same way that only the pre-individual determination of the subject makes it susceptible to modification by itself and by others, through an activity and a technē. This is the true sense of the aesthetics of existence in Foucault, Agamben says: "Happiness - the ethical task par excellence, at which every work on oneself aims - is 'attached' to writing, that is, becomes possible only through a creative practice. The care of the self necessarily passes through an opus" (134). Thus the art of the self, the work on life itself, becomes the most removed from a superficial dandyism and goes on to be the necessary condition for the subject's resistance to the pre-subjective forces of domination. This is how we should understand the epitaph on the gravestone of the painter Paul Klee that Agamben quotes: "a being whose abode is 'just as much with the dead as with the unborn' and who is, for this, 'closer than usual to creation"' (135). And literature becomes, insofar as it is the work of the care of the self, a supplement sine qua non for the ethical configuration of the subject. Or, equally, the ethical subject is, simultaneously and inseparably, an aesthetic subject and a historical subject.

Lastly, we can conclude that between the two fictional times - retrospective and anticipatory - the decentred life is developed as virtual story of the subject that becomes a work of the self. This is because its time is the time of the virtuality that comes from the negative potentiality, that is, from the unfinished nature of the subject. The subject is, therefore, indefinitely open to the outside: the others of the community but also those that have remained outside of history.

24 Agamben again here turns to the mannerist onto-aesthetics of Deleuze in The Fold, already mentioned in the chapter on Sade's irregular subjects. 
The unfinished, open nature of the subject means that, for Agamben, literature is a supplement of being as technology of the work of the self. Literature, as language from death, has the capacity to speak for those that cannot because they have no access. Literature is an opening to the outside, whose time is always deferred by the hermeneutic circle of Nachträglichkeit.

\subsubsection{Subject and History to the "In-temperie"}

Returning to the question left open at the start of this chapter, how does the study of the concept of the subject make it possible to rethink a concept of history, both in crisis? Foucault's proposal of introducing the discontinuity of history in the subject ("History becomes 'effective' to the degree that it introduces discontinuity into our very being”) can equally be read in reverse: thinking history from its concept of subject, which would decentre the temporal limits of its own story: telling our story is to make history.

And, in line with Brown, the critique of the modern subject is also a critique of the liberalism that presupposes sovereign individuals and states as units of analysis and as subjects of action. On the contrary, the subjects we have defined are neither autonomous nor supported upon their autonomy, but are clearly interrelational and only capable of assuming their acts through their non-autonomy.

As Foucault stated in "Utopian Body", the body is presented as a place that roots us in history "now" through death (the corpse) and love. The arguments of Butler and Agamben, based on Foucault, break from the classic concept of a teleological history and make "time now" lead in two contrary directions: the past that precedes and forms us (archaeology) and the future as unfinished potentiality of subjects (care of the self). Two temporalities converge, therefore, in the instant now and make it susceptible to a resignification as resistance to disciplinary powers. In the time of Nachträglichkeit (retroactivity), we are able to rewrite our story contained up until that instant; while in the unfinished moment, we are able to introduce an interruption to the present time, since the mannerist subject or unfinished subject is made responsible for its actions in every moment.

Undoubtedly, this temporality entails a critique of Heidegger's concept of man as "thrown to time", and positions itself closer to Walter Benjamin's consciousness of time, which also introduces discontinuity in the concept of "now" or "now-time" (Jetztzeit).

As Habermas explains in The Philosophical Discourse of Modernity, this discontinuous temporality establishes the possibility of an eruption, an "authentic instant”, of an innovative present-day that interrupts the continuum of history and eludes a homogeneous history. And, as for Benjamin, this reading enables 
us to direct the time of modernity, traditionally joined to the future, toward the past. Hence, only if the subject attends to its past, to memory, can it attend to its present and its future. In this way, an overcoming of the hiatus between experience and expectations of the future is proposed, which, as Reinhart Koselleck showed, in modernity, modern consciousness of time is characterized by the growing distance between "space of experience" and "horizon of expectation", "a permanent global quality of utopian tone" that is, precisely, the breakdown that we currently find ourselves facing. For the first time, principally as a result of studies of ecology and environment, we are confronting a time that does not envisage a better future. The future is once again a source of unease that the time of modernity had neutralized. The subject is faced with a classical time, time as inclemency, time as climatic threat, which brings back the tradition of older times that was characteristic of peasant and artisanal life. However, only if the subject looks to its unfinished nature can it project itself into an open future as a "revolutionary chance in the fight for the oppressed past" (Benjamin, On the Concept of History, Thesis 17). The time of the subject now is not teleological, because, paradoxically, this time as progress had eliminated any possibility of interruption of events, that is, of time as transit. Taking charge of the past is, therefore, for the here-subject, the opening that permits the lack of definition of the time of the subject that dies. The subject that takes charge of its own past thus assumes its ethical responsibility and its freedom. The time of the subject, returned toward its past and projecting toward an unfinished future, creates the possibility of freedom and, at the same time, danger. 
